\title{
Effect of Three Grazing Intervals on Carrying Capacity and Weight Gains Produced by Star Grass Pastures ${ }^{1,2}$
}

\author{
Rubén Caro-Costas and José Vicente-Chandler ${ }^{3}$
}

\begin{abstract}
Intensively managed well fertilized Star grass pastures on a steep Ultisol produced similar weight gains and yields of total digestible nutrients (TDN) and of dry forage with similar protein contents when grazed at 14-, 21-, and 28-day intervals over 3 consecutive years. Average weight gains were 1,197 $\mathrm{kg} / \mathrm{ha} / \mathrm{yr}$; TDN yields were $7,699 \mathrm{~kg} / \mathrm{ha} / \mathrm{yr}$; dry forage consumed by the grazing animals was $12,930 \mathrm{~kg} / \mathrm{ha} / \mathrm{yr}$; and carrying capacity was $5.3273-\mathrm{kg}$ steers/ha. The forage contained an average of $16.8 \%$ crude protein and had an apparent digestibility of $62.7 \%$.

Average monthly weight gains varied considerably throughout the year but were apprently not related to rainfall (fig. 1).

These data show that Star grass pastures can be grazed at intervals varying from 14 to 28 days without affecting their productivity provided that they are grazed no closer than about $20 \mathrm{~cm}$ from the ground and that they are well fertilized. Grazing no closer than $20 \mathrm{~cm}$ leaves sufficient photosynthetic area and enough root reserves are maintained to ensure rapid regrowth of the grass after grazing.
\end{abstract}

\section{INTRODUCTION}

Star grass (Cynodon nlemfuensis) is rapidly becoming the most widely planted pasture grass in the humid region of Puerto Rico. Caro-Costas and Vincent-Chandler (4) found that Star grass pastures responded, in terms of beef production and carrying capacity, to applications of up to 3,180 kg of a 15-5-10 fertilizer/ha/yr. Caro-Costas and Vincente-Chandler (3) found that Star grass pastures outyielded those of Pangola grass, producing over $1,500 \mathrm{~kg} / \mathrm{ha} / \mathrm{yr}$ of gain in liveweight when fertilized with 2,270 kg of 15-5-10 fertilizer/ha/yr. Caro-Costas et al. (2) found that yields of Star grass harvested by cutting increased with length of harvest interval up to 60 days. Rodríguez and Silva (5) found that a better stand of Star grass was maintained with high $(15-20 \mathrm{~cm})$ than with low (2.5-7.5 $\mathrm{cm}$ ) grazing. They also found that with low grazing the stand of Star grass increased with length of grazing interval, but with high grazing, grazing interval had little effect on stand.

The present study determined the effect of three grazing intervals on

${ }^{1}$ Manuscript submitted to Editorial Board November 7, 1979.

${ }^{2}$ This report covers work conducted cooperatively by Agricultural Research, Science and Education Administration, USDA and the Agricultural Experiment Station, Mayagüez Campus, University of Puerto Rico, Río Piedras, P.R.

${ }^{3}$ Associate Agronomist, Agricultural Experiment Station and Soil Scientist-Location Leader, Agricultrual Research, Science and Education Administration, USDA, Río Piedras, P.R., respectively. 
the productivity of a well-managed Star grass pasture in terms of weight gains and carrying capacity.

\section{MATERIALS AND METHODS}

The experiment was carried out over a 3-year period at the Corozal Substation of the Agricultural Experiment Station located at an elevation of about $200 \mathrm{~m}$. Mean annual temperature is about $25^{\circ} \mathrm{C}$ and mean monthly variations are about $5^{\circ} \mathrm{C}$. Annual rainfall is about $1,600 \mathrm{~mm}$ fairly well distributed throughout the year. The soil is a deep, red, Corozal clay (Aquic Tropudults) on a $25 \%$ slope.

Twelve 0.4-ha plots of Star grass were used in the experiment. All pastures were provided with water and salt, the soil was limed to $\mathrm{pH} 6.0$, and $560 \mathrm{~kg}$ of 15-5-10 fertilizer were applied/ha every 3 months.

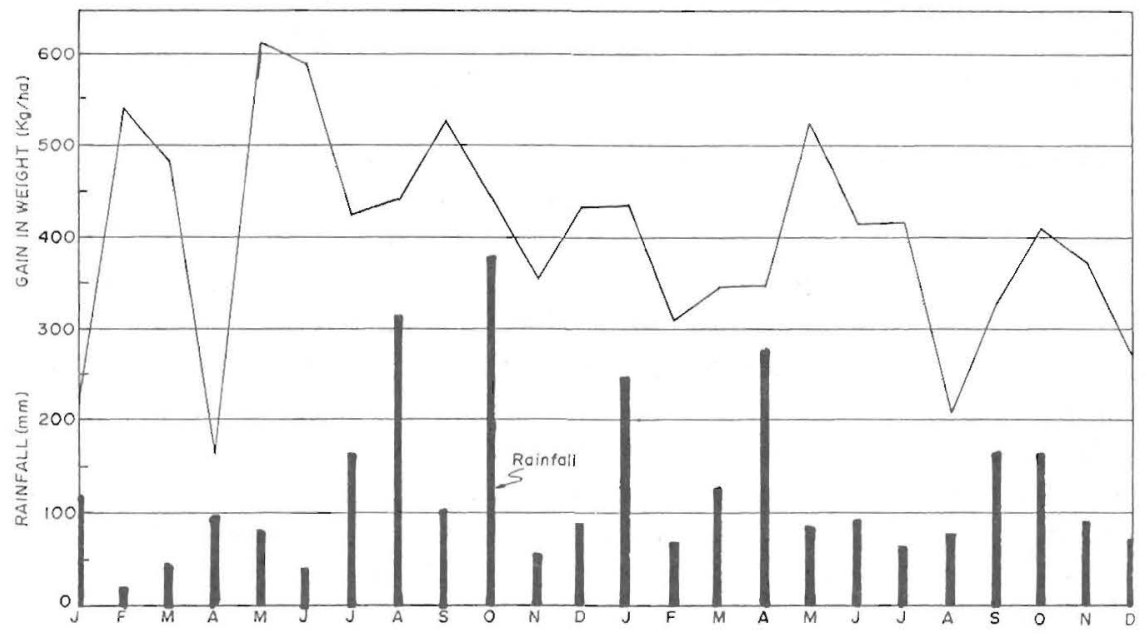

FIG. 1.-Average monthly weight gain made by young Holstein heifers grazing well managed and fertilized Star grass pastures over a 2-year period at Corozal.

Treatments consisted of grazing the pastures at 14-, 21- and 28-day intervals. The forage in each pasture was grazed down to a height of about $20 \mathrm{~cm}$ during each grazing round. A complete randomized block design was used with all treatments replicated four times.

The pastures were grazed by young Holstein heifers which were treated periodically for parasites and received no feed other than that obtained from the pastures. The heifers initially weighed about $160 \mathrm{~kg}$ and were replaced yearly. A different group of heifers grazed the astures assigned to each grazing interval. Five "tester" heifers were kept per hectare throughout the year on all treatments. Additional heifers were added as required to consume excess forage using the "put and take" system. 
These heifers were used very little, and since there was little difference in productivity of the pastures, the heifers were used in equal numbers and over similar periods of time in all treatments.

At the end of each year of grazing, the pastures were rested for about 1 month while a new group of heifers were prepared for use in the experiment. The first round of grazing following this period was used to accustom the heifers to the management regime and conditions of the experimental area. The data obtained were not used in determining the productivity of the pastures. The heifers were not bred during the experiment.

The heifers were weighed each time they were moved from one pasture to another. A record was kept of the grazing days and weight gains for each animal and each pasture. The total digestible nutrients (TDN) produced by each pasture and its carrying capacity were calculated from these data, following recommendations of the Pasture Research Committee (1). Carrying capacities were expressed in terms of 273-kg steers/ ha.

During the second year, half of eight $1 \times 2 \mathrm{~m}$ areas in each pasture was cut to ground level before each grazing. The other half was cut after each grazing. In both cases the harvested forage was weighed and dried. From these data the amount of dry forage actually consumed by the grazing cattle was determined by difference. The sample areas were varied during each grazing cycle so that the data would reflect the effects of trampling and grazing.

Also during the second year, 10 forage samples from each plot were taken before each grazing by plucking in such a way as to simulate grazing. These samples, which were considered to be typical of the forage ingested by the grazing cattle, were analyzed for crude protein, $\mathrm{Ca}, \mathrm{P}$, and lignin.

\section{RESULTS AND DISCUSSIONS}

Annual rainfall at the experimental site during the course of the experiment ranged from 1,438 to $1,629 \mathrm{~mm}$ averaging $1,521 \mathrm{~mm}$ yearly/ (table 1). Monthly rainfall ranged from 21 to $378 \mathrm{~mm}$.

Grazing intervals varying from 14 to 28 days did not significantly affect weight gains, average daily gain/head, carrying capacity, and TDN produced by the Star grass (table 2).

On the average, these well fertilized Star grass plots carried the equivalent of $5.28273-\mathrm{kg}$ steers/ha throughout the year, and produced 7,699 $\mathrm{kg}$ of TDN $/ \mathrm{ha} / \mathrm{yr}$ and 1,197 kg of weight gain/ha/yr. The heifers gained an average of $0.52 \mathrm{~kg} /$ day.

Yields of dry forage consumed by the grazing cattle, averaging 12,950 $\mathrm{kg} / \mathrm{ha} / \mathrm{yr}$ during the second year (table 3 ), were not significantly affected by grazing intervals. 
Apparent digestibility of the forage, likewise not affected by grazing interval, averaged $62.7 \%$ for all treatments during the second year (table $3)$.

Average annual weight gains for all grazing intervals varied from 1,144 $\mathrm{kg} / \mathrm{ha} / \mathrm{yr}$ in 1975-76 to 1,323 in 1976-77 (table 4). There were no significant differences between treatments during any year.

TABLE 1.-Monthly rainfall $(\mathrm{mm})$ at Corozal during the 3 years of experimentation

\begin{tabular}{lrrrr}
\hline \multicolumn{1}{c}{ Month } & $\begin{array}{c}\text { First } \\
\text { year }\end{array}$ & $\begin{array}{c}\text { Second } \\
\text { year }\end{array}$ & $\begin{array}{c}\text { Third } \\
\text { year }\end{array}$ & Average \\
\hline January & 144 & 97 & 122 & 121 \\
February & 21 & 119 & 22 & 54 \\
March & 141 & 130 & 49 & 107 \\
April & 56 & 145 & 98 & 100 \\
May & 53 & 78 & 80 & 70 \\
June & 24 & 35 & 42 & 34 \\
July & 74 & 35 & 165 & 91 \\
August & 178 & 96 & 315 & 196 \\
September & 183 & 235 & 103 & 174 \\
October & 201 & 378 & 98 & 226 \\
November & 274 & 56 & 295 & 208 \\
December & 280 & 90 & 49 & 140 \\
\hline Total & 1,629 & 1,494 & 1,438 & 1,521 \\
\hline
\end{tabular}

TABLE 2.-Effect of three grazing intervals on weight gain and carrying capacity of a well fertilized Star grass pasture over a 3-year period at Corozal

\begin{tabular}{ccccc}
\hline $\begin{array}{c}\text { Grazing } \\
\text { interval }\end{array}$ & $\begin{array}{c}\text { Weight } \\
\text { gan's }\end{array}$ & $\begin{array}{c}\text { Total } \\
\text { digestible } \\
\text { nutrients }\end{array}$ & $\begin{array}{c}\text { Carrying } \\
\text { capacity }\end{array}$ & $\begin{array}{c}\text { Average } \\
\text { daily } \\
\text { gain } \\
\text { per head }\end{array}$ \\
\hline Days & $K g / h a / y{ }^{*}$ & $K g / h a / y r$ & 273 -kg steers/ha & $\mathrm{Kg}$ \\
14 & 1,242 & 7,538 & 5.16 & .52 \\
21 & 1,239 & 8,056 & 5.52 & .54 \\
28 & 1,110 & 7,503 & 5.14 & .51 \\
\hline & N.S. ${ }^{4}$ & N.S. & N.S. & N.S. \\
\hline
\end{tabular}

${ }^{1}$ Calculated from body weights, days of grazing and weight gain following recommendations of the Pasture Research Committee (1).

${ }^{2}$ One $273 \mathrm{~kg}$ steer requires $3.86 \mathrm{~kg}$ of TDN daily for maintenance and weight gain of 0.5 $\mathrm{kg}$.

${ }^{3}$ For tester cattle which remained on the pastures throughout the year.

${ }^{4}$ Nonsignificant difference at the $5 \%$ probability level.

Grazing interval did not affect protein content of the forage consumed by the grazing cattle, which averaged $17.0,16.9$, and $16.7 \%$ with the 14-, 21- and 28-day grazing intervals, respectively (table 5). Protein content varied considerably from month to month ranging from 13.4 to $21 \%$. Protein content of the forage throughout the year was well above the requirements for young growing heifers. No significant relationship was 
TABLE 3.-Effect of three grazing intervals on productivity of a well fertilized Star grass pasture over the second year of experimentation

\begin{tabular}{|c|c|c|c|c|c|}
\hline $\begin{array}{l}\text { Grazing } \\
\text { interval }\end{array}$ & $\begin{array}{l}\text { Weight } \\
\text { gain }\end{array}$ & & $\begin{array}{l}\text { Total Digestible } \\
\text { nutrients }^{1}\end{array}$ & $\begin{array}{l}\text { Dry forage con- } \\
\text { sumed by graz- } \\
\text { ing cattle }\end{array}$ & $\begin{array}{l}\text { Apparent diges- } \\
\text { tibility of in- } \\
\text { gested forage }\end{array}$ \\
\hline Days & $K g / h a / y r$ & & $K g / h a / y r$ & $\mathrm{Kg} / \mathrm{ha} / \mathrm{yr}$ & $\%$ \\
\hline 14 & 1,384 & & 8,250 & 12,440 & 66.3 \\
\hline 21 & 1,343 & & 8,210 & 13,030 & 62.9 \\
\hline \multirow[t]{2}{*}{28} & 1,247 & & 7,850 & 13,380 & 59.0 \\
\hline & N.S. ${ }^{3}$ & N.S. & N.S. & N.S. & N.S. \\
\hline
\end{tabular}

${ }^{1}$ One 273 -kg steer requires $3.86 \mathrm{~kg}$ of TDN daily.

${ }_{2}$ Forage consumed

$$
\text { TDN }
$$

${ }^{3}$ Nonsignificant difference at the $5 \%$ probability level.

TABLE 4.-Annual average weight gain $(\mathrm{kg} / \mathrm{ha})$ for each grazing interval

\begin{tabular}{crrrr}
\hline Grazing interval & $1975-76$ & $1976-77$ & $1977-78$ & Average \\
\hline Days & & & & \\
14 & 1,166 & 1,384 & 1,177 & 1,242 \\
21 & 1,166 & 1,343 & 1,207 & 1,239 \\
28 & 1,098 & 1,247 & 986 & 1,110 \\
Average & 1,144 & 1,323 & 1,123 & 1,197 \\
\hline & N.S. & N.S. & N.S. & N.S. \\
\hline
\end{tabular}

${ }^{1}$ Nonsignificant difference at the $5 \%$ probability level.

TABLE 5.-Protein content (\%) of Star grass forage obtained over a 1-year period by plucking to simulate grazing, as affected by season of the year and grazing interval

\begin{tabular}{lccc}
\hline \multirow{2}{*}{ Month } & \multicolumn{3}{c}{ Grazing interval (days) } \\
\cline { 2 - 4 } & 14 & 21 & 28 \\
\hline January & 17.9 & 16.6 & 17.0 \\
February & 20.4 & 21.0 & 20.1 \\
March & 14.9 & 14.5 & 15.9 \\
April & 18.2 & 18.8 & 19.5 \\
May & 18.6 & 17.9 & 16.5 \\
June & 15.3 & 14.5 & 14.9 \\
July & 17.9 & 17.1 & 16.0 \\
August & 17.0 & 18.5 & 17.6 \\
September & 15.7 & 16.9 & 15.9 \\
October & 14.0 & 13.9 & 13.4 \\
November & 17.6 & 16.8 & 16.0 \\
December & 16.6 & 16.9 & 17.2 \\
\hline Average & 17.0 & 16.9 & 16.7 \\
\hline
\end{tabular}

found to exist between percent protein content of the forage and monthly gains.

Although protein and calcium content of the forage were not affected by grazing interval, phosphorus content was significantly higher when the pastures were grazed every 14 days (table 6). 
STAR GRASS GRAZING INTERVALS: CAPACITY, GAINS

TABLE 6.-Average composition of Star grass forage obtained by plucking to simulate grazing over a 1-year period, as affected by three grazing intervals

\begin{tabular}{cccc}
\hline \multirow{2}{*}{ Grazing interval } & \multicolumn{3}{c}{ Composition (\%) } \\
\cline { 2 - 4 } & Crude protein & Calcium & Phosphorus \\
\hline Days & 17.0 & 0.50 & $0.28^{\mathrm{a} 1}$ \\
14 & 16.9 & 0.46 & $0.16^{\mathrm{b}}$ \\
21 & 16.7 & 0.45 & $0.18^{\mathrm{b}}$ \\
28 & N.S. & N.S. & \\
\hline
\end{tabular}

${ }^{1}$ Values followed by the same letter do not differ significantly at the $5 \%$ level (Duncan's new multiple range test).

${ }^{2}$ Difference nonsignificant at the $5 \%$ probability level.

Average monthly weight gains varied considerably throughout the year but were apparently not related to rainfall (fig. 1).

These data show that Star grass pastures can be grazed at intervals varying from 14 to 28 days without affecting their productivity provided that they are grazed no closer than about $20 \mathrm{~cm}$ from the ground and that they are well fertilized. Grazing no closer than $20 \mathrm{~cm}$ leaves sufficient photosynthetic area and enough root reserves are maintained to ensure rapid regrowth of the grass after grazing.

If repeatedly grazed close to the ground at short intervals the stand of Star grass will deteriorate and weeds will invade the pastures as shown by Rodríguez and Silva (5).

\section{RESUMEN}

Se determinó el efecto de intervalos de pastoreo de 14, 21 y 28 días en la productividad de pastos Estrella en un suelo Corozal durante 3 años consecutivos. Los pastos se abonaron con $550 \mathrm{~kg}$ de un análisis $15-5-10 /$ ha cada 3 meses y se pastaron con novillas Holstein a una altura de $20 \mathrm{~cm}$.

Los intervalos entre pastoreos no afectaron el aumento de peso en las novillas ni la producción de nutrimentos digeribles o de forraje. Tampoco afectaron el contenido en proteína bruta del forraje ni su digestibilidad aparente.

En promedio, los pastos produjeron $1,197 \mathrm{~kg}$ en aumento de peso/ha y año, $7,699 \mathrm{~kg}$ de nutrimentos digeribles/ha y año, y $12,950 \mathrm{~kg} / \mathrm{ha}$ y año de forraje seco. La capacidad de pastoreo fue equivalente a 5.3 cabezas con un peso medio de $273 \mathrm{~kg} / \mathrm{ha}$. El contenido de proteína bruta del forraje fue de $16.8 \%$ y la digestibilidad aparente de $62.7 \%$.

Estos datos demuestran que los pastos Estrella bien abonados y pastados a una altura de no menos de $20 \mathrm{~cm}$ mantienen una productividad similar cuando se pastan a intervalos de 2, 3 ó 4 semanas brindándole así flexibilidad al ganadero en el uso de los mismos. 


\section{LITERATURE CITED}

1. Anonymous, 1943. Report on pasture investigations techniques, Joint Comm. Am. Dairy Sci. Assoc., Soc. Agron., and Am. Soc. An. Prod. J. Dairy Sci. 26:353-69.

2. Caro-Costas, R., Abruña, F., and Figarella, J., 1972. Effect of nitrogen rates, harvest intervals and cutting heights on yield and composition of Star grass in Puerto Rico, J. Agri. Univ. P.R. 56 (3):267-79.

.3 - __, and Vicente-Chandler, J., 1972. Comparison of heavily fertilized Pangola and Star grass pastures in terms of beef production and carrying capacity in the humid mountain region of Puerto Rico, J. Agri. Univ. P.R. 56 (2):104-19.

4. - - - - , and - - 1976. Effect of three levels of fertilization on the production of Star grass pastures, J. Agri. Univ. P.R. 60 (2):172-8.

5. Rodríguez, J. A. and Silva, S., 1975. Effect of two heights and three intervals of grazing on stand of a heavily fertilized Star grass pasture, J. Agri. Univ. P.R. 54 (3):214-9.

6. Vicente-Chandler, J., Abruña, F., Caro-Costas, R., Figarella, J., Silva, S., and Pearson, R. W., 1974. Intensive grassland management in the humid tropics of Puerto Rico, Agri. Exp. Stn. Univ. P.R., Bull. 233. 